\title{
Development of sensitized solar cells by photosynthetic pigments
}

\author{
lara Mendes Maciel ${ }^{1 *}$, Maria José Otero Martino², Raúl Barba Tamaro², Luis José Andrés Menendez ${ }^{3}$ \\ From 5th Congress of the Brazilian Biotechnology Society (SBBIOTEC) \\ Florianópolis, Brazil. 10-14 November 2013
}

\section{Background}

Grätzel solar cell, also known as dye-sensitized solar cell (DSSC), is a dye-sensitized nanocrystalline photovoltaic cell of $\mathrm{TiO}_{2}$ (titanium dioxide). It has a surface of nanoporous $\mathrm{TiO}_{2}$, a semiconductor of a wide bandgap. The basic principle is to transform light energy into electrical energy. When a dye molecule absorbs light, an electron is replaced by an excited state, and this dye can jump to the conduction band of $\mathrm{TiO}_{2}$. In the composite electrode, the electron diffuses from this $\mathrm{TiO}_{2}$ to the conductive glass. From there, the electron is taken to the electrode through a conductor. Similar to this process, the plant cell transforms the light into energy using photosynthetic pigments for absorption and many other mechanisms for the transfer and storage of energy, by a process known as photosynthesis. Observing and analyzing these methods, our objective was to use some photosynthetic pigments found in plants in Grätzel solar cells to evaluate the potential use of these pigments in the production of solar panels.

\section{Methods}

The extraction of pigments was performed of 4 algae: Codium tomentosum (CT), Ulva lactuca (UL), Ahnfeltia plicata (AP), Pterosiphonia complanata (PC); 2 fruits: Rubus ulmifolius (ANM), Prunus spinosa (AN); and spinach leaves: Spinacia oleracea (CL), using 100\% acetone in the case of algae and leaves (extraction of chlorophylls, carotenoids and xanthophylls) and $0.1-1 \% \mathrm{HCl}(\mathrm{pH}<2)$ in ethanol in the case of the fruits (extraction of anthocyanins).

A TLC was performed with a filter paper using a mixture of hexane:acetone (7:3), an absorbance reading of the extracts for the separation and a verification of pigments found in each sample.

${ }^{1}$ Universidade Federal de Goiás, Goiânia, Goiás, Brazil

Full list of author information is available at the end of the article
Subsequently, DSSCs were constructed. Was added a $\mathrm{TiO}_{2}$ (liq) layer in the conductive glass, heated at $450^{\circ} \mathrm{C}$ to attach to the glass layer. Then, submerged in the pigments solutions for 24 hours. After that, another conductive glass scratched with graffiti was arranged and closed up with tweezers. A few drops of solution iodine/iodide were added. The DSSCs were connected in a multimeter and were putted in a solar simulator, with the objective of measuring the voltage when stimulated and unstimulated by light in different time periods.

\section{Results and conclusions}

Analyzing the samples voltage in the presence and absence of light, it can be concluded that the voltage produced in the absence of light is insignificant when compared to the voltage at light.

Of all samples measured, the ones that showed the best results in relation of the voltage and stability over a certain period of time were those with a higher proportion of chlorophyll: UL and AP. CL also showed elevated values, though quite ranged over the days, which may be due the degradation of the pigment. PC and AN had high stability but very low voltage. ANM showed irregular and low results.

Continuing with the samples for several days, it might be concluded that the cells with pigments of AP and UL remain in operation longer than expected, and UL, moreover, maintains stability. Thus, the use of photosynthetic pigments for the solar cells production from this study is feasible.

\section{Acknowledgements \\ Thanks to ITMA, UniOvi, CNPq and the program "Science without Borders". \\ Authors' details \\ 'Universidade Federal de Goiás, Goiânia, Goiás, Brazil. ²Universidad de Oviedo, Oviedo, Asturias, Spain. ${ }^{3}$ TMA Materials Technology, Avilés, Asturias, Spain.}



and take full advantage of:

- Convenient online submission

- Thorough peer review

- No space constraints or color figure charges

- Immediate publication on acceptance

- Inclusion in PubMed, CAS, Scopus and Google Scholar

- Research which is freely available for redistribution 